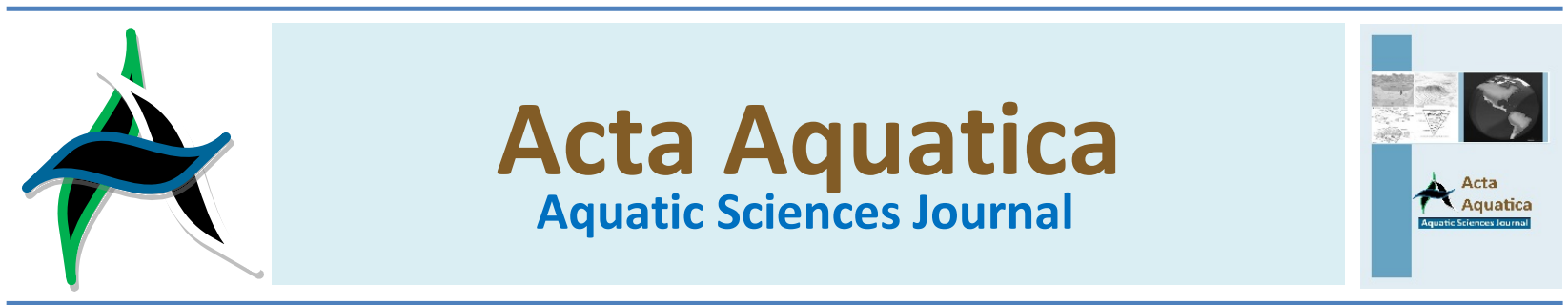

Skrining fitokimia dan profil kromatografi lapis tipis dari tumbuhan mangrove family Rhizopohoraceae dan Aviceniaceae

\title{
Phtytochemical screening and thin layer choromatography (TLC) profiling of mangrove family Rhizophoraceae and Avicenniaceae
}

\author{
Andriani Rafael a,b,* \\ anstitute of Environmental and Marine Sciences, Silliman University, Dumaguete City, Negros Oriental, Philippines \\ bUniversitas Kristem Artha Wacana, Kupang, Nusa Tenggara Timur, Indonesia
}

Abstrak

Penelitian ini telah dilakukan pada bulan Februari sampai dengan April 2017. Sampel dari kulit batang dari 7 spesies mangrove yaitu Ceriops decandra (Griff.) Ding Hou; Ceriops tagal (Perr.) C.B. Rob.; and Bruguiera cylindrica; Bruguiera gymnorrhiza (L) Lam; Rhizophora stylosa Griff.; Rhizophora mucronata Lam.; and Avicennia marina (Forsk.) Vierh diteliti. Analisis fitokimia dan profil KLT dari ekstrak kasar batang mangrove diteliti dan dibandingkan. Analisis kualitatif menunjukkan bahwa kulit batang Ceriops decandra (Griff.) Ding Hou, Ceriops tagal (Perr.) C.B. Rob., Bruguiera cylindrica, Bruguiera gymnorrhiza (L) Lam, Rhizophora stylosa Griff., Rhizophora stylosa Griff., Rhizophora mucronata Lam., and Avicennia marina (Forsk.) Vierh. mengandung beberapa metabolit sekunder penting seperti kandungan fenol, tanin dan flavonoid. Flavonoid ditemukan pada Avicennia marina (Forsk.) Vierh. Profil KLT menunjukkan bahwa perbandingan nilai Rf standar dan Rf sampel, 2 noda yang terdapat pada kromatogram dari ekstrak kasar Rhizophora stylosa Griff sama dengan nilai Rf standar (Rf Flavonoid glikosida $=0.18 ; 0.26 ; 0,30$ ) mengindikasikan bahwa $R$. stylosa Griff diduga mengandung Flavonoidglikosida dan asam fenolik (nilai Rf Asam fenolik=0,63-0,84). Sementara Avicennia marina (Forsk.) Vierh. diduga mengandung asam fenolik. Oleh karena itu, beberapa kandungan senyawa yang belum teridentifikasi, diperlukan penelitian yang leih lanjut.

Kata kunci: mangrove, fitokimia, kromatografi lapis tipis

\begin{abstract}
This research was carried out from February to April 2017. The barks from seven mangrove species viz., Ceriops decandra (Griff.) Ding Hou; Ceriops tagal (Perr.) C.B. Rob.; and Bruguiera cylindrica; Bruguiera gymnorrhiza (L) Lam; Rhizophora stylosa Griff.; Rhizophora mucronata Lam.; and Avicennia marina (Forsk.) Vierh was examined. The phytochemicals analysis and TLC profiling from the bark's crude extracts were examined and compared. The qualitative analysis indicates that the barks of Ceriops decandra (Griff.) Ding Hou, Ceriops tagal (Perr.) C.B. Rob., Bruguiera cylindrica, Bruguiera gymnorrhiza (L) Lam, Rhizophora stylosa Griff., Rhizophora mucronata Lam., and Avicennia marina (Forsk.) Vierh. possess some important secondary metabolites, i.e, Phenol, Tannin, and Flavonoid compounds. Flavonoid is present only in Avicennia marina (Forsk.) Vierh. TLC profiling indicate that in comparison with standard $R_{f}$ value, two spots in the chromatogram of crude extracts of Rhizophora stylosa Griff. equal to the standard values ( $R_{f}$ values of Flavonoid-glycoside fell between $=0.18 ; 0.26 ; 0.30)$ indicated that Rhizophora stylosa Griff may contain Flavonoid-glycoside and phenolic acid $\left(R_{f}\right.$ values of phenolic acid, 0.63-0.84). Whereas, Avicennia marina (Forsk.) Vierh may contain phenolic acid. However, there are unknown compound that need to be identified in further research.
\end{abstract}

Key words: mangrove, phytochemical, thin layer chromatography

\section{Pendahuluan}

Mangrove didefinisikan sebagai pohon dan semak yang memiliki kemanpuan untuk tumbuh di pesisir pantai. Mangrove tumbuh di lingkungan dengan kondisi lingkungan ekstrim seperti daerah

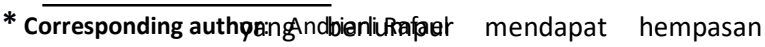
Tel: +6281385270809

Present Address: Biology Study Program, Faculty of Teacher Training and Education, Artha Wacana Christian University, Kupang, East Nusa Tenggara, Indonesia

E-mail address: andriani.rafael2013@gmail.com ombak pasang dan surut lingkungan dengan kadar garam yang tinggi. Oleh karena kemampuan adapatsinya yang unik sehingga mangrove memiliki banyak senyawa bioaktif yang memiliki manfaat secara ekologis, farmakologis, dan toksikologis. (Tong et al., 2006).

Di Filipina, hutan mangrove memberikan banyak manfaat bagi kehidupan masyarakat yang hidup di pesisir pantai. Secara tradisional, mangrove digunakan sebagai 
sumber kayu bakar, bahan dasar arang, bahan bangunan dan pengobatan secara tradisional. Sedangkan manfaat secara ekologi adalah berfungsi sebagai proteksi biologis terhadap erosi pantai, dapat mengurangi dampak badai tropik serta tsunami (Alongi, 2008; Giri et al., 2008).

Penelitian yang di lakukan oleh Fauvel et al., (1993), yang mengektraski senyawa metabolit sekunder dari batang, daun dan buah dari Avicennia marina, digunakan sebagai obat tradisonal untuk menngobati kanker kulit ekstraksi senyawa kimia menggunakan pelarut methanol dari daun dan ranting $A$. marina mempunyai manfaat sebagai sebagai anti bakteri, anti jamur, antiokisdan dan anti karsinogenik (Zhu et al., 2009). Selain itu, ekstrak methanol dari daun Rhizophora mucronato memiliki potensi sebagai antioksidan (Bunyapraphatsara et al., 2003). Penelitian ini bertujuan untuk mengetahui kandungan senyawa metabolit sekunder pada kulit batang mangrove famili Rhizophoraceae dan Aviceniacea menggunakan pelarut etanol melalui skrining fitokimia dan metode kromatografi lapis tipis (KLT).

\section{Metode penelitian}

\subsection{Waktu dan tempat}

Penelitian ini dilakukan pada bulan Februari sampai dengan bulan April 2017. Sampel kulit batang mangrove diambil di area hutan mangrove Institute of Environmental and Marine Sciences (IEMS), Silliman University, Kota Dumaguete, Filipina. Area mangrove ini yang merupakan laboratorium botani dan juga sebagai tempat penelitian bagi mahasiswa IEMS di tahun 1990, dengan luas area 1 hektar. Sebanyak 29 spesies mangrove yang dikelompokkan menjadi 18 famili ditemukan di area ini (Gambar 1).

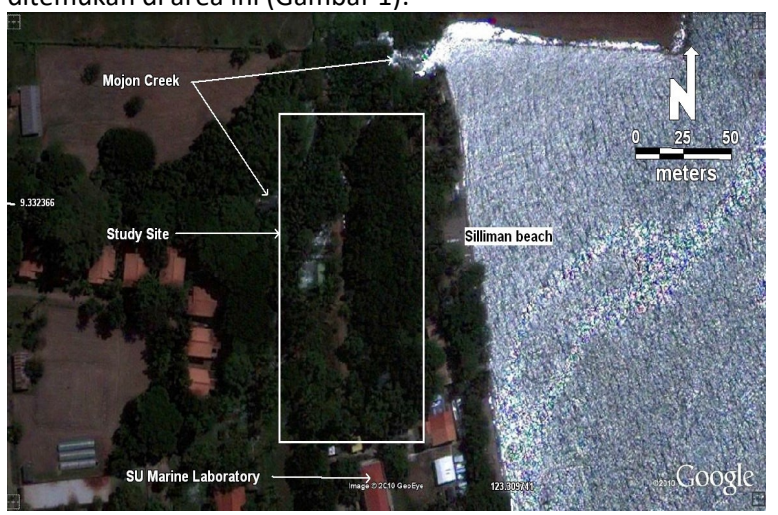

Gambar 1. Peta lokasi Penelitian IEMS-Universitas Silliman

\subsection{Alat dan bahan}

Alat yang digunakan dalam oeneltian ini adalah etanol, $\mathrm{FeCl} 3, \mathrm{Mg}$, aguades, vacuum rotary evaporator, water bath, Erlenmeyer, kertas saring Whatman No.42, tabung reaksi, rak tabung reaksi, pipet tetes, plat KLT. Bahan yang digunakana dalam penelitian ini adalah serbuk kulit batang dari 7 spesies mangrove dari 2 famili yaitu Rhziphoraceae dan Avicenniaceae.

\subsection{Prosedur penelitian}

\subsubsection{Pengambilan sampel}

Sampel kulit batang mangrove diambil menggunakan pisau dengan lokasi hutan mangrove Institute of Environmental and Marine Sciences (IEMS), Silliman University. Sampel kulit mangrove yang sudah diambil kemudian dimasukan dalam zipper plastic dan diberi label. Selanjutnya sampel-sampel tersebut akan dikeringanginkan selama 2 hari sebelum digiling menjadi serbuk.

\subsubsection{Preparasi Sampel}

Serbuk batang kulit mangrove dibuat dari $20 \mathrm{~g}$ kulit batang basah yang berasal dari 7 spesies mangrove yaitu Ceriops decandra (Griff.) Ding Hou; Ceriops tagal (Perr.) C.B. Rob. Rhizophora stylosa Griff.; Rhizophora mucronata Lam.; Bruguiera cylindrical (L.) Blume, Bruguiera gymnorrhiza (L) Lam; dan Avicennia marina (Forsk.) Vierh. Kulit batang dikeringkan, kemudian digiling menggunakan mortar menjadi bentuk serbuk. Total sample yang diperoleh untuk masing spesies yaitu $10 \mathrm{~g}$.

\subsubsection{Ekstraksi Sampel}

Serbuk kulit batang dari C. decandra, C. tagal, $R$. stylosa, R. mucronata, B. cylindrica, B. gymnorrhiza dan A. marina dimaserasi dengan etanol selama $3 \times 24$ jam, kemudian di saring dengan kertas saring Whatman No. 42, diuapkan dengan vacuum rotary evaporator pada suhu $40^{\circ} \mathrm{C}$ sampai diperoleh filtrat yang pekat, bebas pelarut.

\subsubsection{Identifikasi Kandungan Kimia}

Uji kualitatif kandungan kimia dalam ekstrak etanol kulit batang $C$. decandra, $C$. tagal, $R$. stylosa, $R$. mucronata, $B$. cylindrica, B. gymnorrhiza, dan A. marina, dilakukan dengan pereaksi kimia untuk mengidentifikasi golongan fenol, flavonoid, dan tanin. Metode identifikasi kandungan kimia di modifikasi menurut Tamilselvi et al., (2012), Maobe et al., (2012) Lakshmanan et al., (2013).

Uji Fenol: sampel ekstrak kasar sebanyak $2 \mathrm{~mL}$ dimasukan kedalam tabung reaksi dan ditambahkan $5 \mathrm{~mL}$ aquades. Kemudian ditambahkan 3 tetes ferri klorida ( $\mathrm{FeCl} 3$ ). Adanya senyawa fenolik ditandai dengan terbentuknya warna hijau pekat atau biru.

Uji Tanin: sampel ekstrak kasar sebanayak $2 \mathrm{~mL}$ dilarutkan dengan $5 \mathrm{~mL}$ aquades dalam tabung reaksi dan di panaskan menggunakan water bath. Kemudian ditambahkan 3 tetes larutan ferri klorida ( $\mathrm{FeCl} 3 \mathrm{10 \%}$ ). Adanya warna hijau atau hitam kebiruan, atau coklat mengindikasikan adanya senyawa tanin.

Uji Flavonoid: sampel ekstrak kasar sebanayak $2 \mathrm{~mL}$ dipanaskan dengan water bath, kemudian ditambahkan serbuk $\mathrm{Mg}$ dan 6 tetes asam klorida $(\mathrm{HCl})$ pekat. Warna pink, atau merah atau hijau menandakan adanya senyawa flavonoid.

\subsubsection{Kromatografi Lapis Tipis (KLT)}


Kromatografi Lapis Tipis dilakukan dengan mengaplikasikan 0,15 mL ekstrak kasar pada plat KLT. Pelarut yang digunakan yaitu butanol: etanol: aquades dengan perbandingan 40:10:50 (v/v). Beaker glass dengan ukuran 250 $\mathrm{mL}$ disiapkan dan Plat KLT ditempatkan dibagian dasar beaker glass dengan kemiringan $45^{\circ} \mathrm{C}$ dan ditutup dengan kaca arloji dan memastikan bahwa pelarut tepat di bawah totolan sampel. Plat KLT diangkat setelah sekitar \pm 30 menit ketika pelarut naik mendekati garis tepi atas. Selanjutnya plat KLT diangkat dengan menggunakan pinset dan dikeringanginkan. Metode dimodifikasi dari Asha et al., (2012) dan Maobe et al., (2012).

Plat KLT diperiksa a di bawah sinar UV pada panjang gelombang $254 \mathrm{~nm}$. Totolan yang digerakkan oleh pelarut ditandai dengan pensil. Jarak perpindahan sampel oleh pelarut diukur menggunakan penggaris. Faktor retensi $\left(R_{f}\right)$ sampel kemudian ditentukan berdasarkan rumus menurut Cetkovic et al., (2003) jarak yang ditempuh oleh senyawa dibagi dengan jarak yang ditempuh oleh pelarut. Nilai $R_{f}$ dapat ditentukan menggunakan rumus dibawah ini:

$\mathrm{R}_{\mathrm{f}}=\quad$ Jarak yang ditempuh oleh senyawa

Nilai $R_{f}$ yang diperoleh dari sampel akan dibandingkan dengan nilai $R_{f}$ dari senyawa-senyawa metabolit sekunder berdasarkan referensi.

\subsection{Parameter Penelitian}

Paramter yang diamati adalah adanya perubahan warna dari sampel ekstrak kasar kulit batang mangrove dan faktor retardasi (Rf) dari profil KLT dari 7 spesies mangrove.

\subsection{Analisis Data}

Semua data yang diperoleh dianalias secara deskriptif kualitatif.

\section{Hasil dan pembahasan}

\subsection{Skrining fitokimia}

Data hasil uji fitokimia terhadap senyawa metabolit sekunder ekstrak kasar kulit batang dari 7 spesies mangrove ditampilkan pada tabel 1 dan gambar 1 (a) sampai dengan $1(f)$. Tabel 1.

Hasil Analisis Fitokimia pada Kulit Batang Mangrove

\begin{tabular}{|c|c|c|c|}
\hline \multirow[t]{2}{*}{ Ekstrak Kasar } & \multicolumn{3}{|c|}{ Paramater } \\
\hline & Uji Fenol & Uji Flavonoid & Uji Tanin \\
\hline $\begin{array}{l}\text { Ceriops decandra } \\
\text { (Griff.) Ding Hou }\end{array}$ & $\begin{array}{c}+ \\
\text { (hijau } \\
\text { pekat) }\end{array}$ & $\begin{array}{c}- \\
\text { (kuning) }\end{array}$ & $\begin{array}{c}+ \\
\text { (coklat } \\
\text { muda) }\end{array}$ \\
\hline $\begin{array}{l}\text { Ceriops tagal } \\
\text { (Perr.) C.B. Rob. }\end{array}$ & $\begin{array}{c}+ \\
\text { (hijau } \\
\text { pekat) }\end{array}$ & $\begin{array}{c}- \\
\text { (kuning) }\end{array}$ & $\begin{array}{c}+ \\
\text { (coklat } \\
\text { muda) }\end{array}$ \\
\hline $\begin{array}{l}\text { Bruguiera } \\
\text { cylindrical }\end{array}$ & $\begin{array}{c}+ \\
\text { (hijau } \\
\text { pekat) }\end{array}$ & $\begin{array}{c}- \\
\text { (kuning) }\end{array}$ & $\begin{array}{c}+ \\
\text { (coklat } \\
\text { muda) }\end{array}$ \\
\hline Bruguiera & + & - & + \\
\hline
\end{tabular}

\begin{tabular}{|c|c|c|c|}
\hline gymnorrhiza (L) & $\begin{array}{l}\text { (hijau } \\
\text { pekat) }\end{array}$ & (kuning) & $\begin{array}{l}\text { (coklat } \\
\text { muda) }\end{array}$ \\
\hline $\begin{array}{l}\text { Rhizophora } \\
\text { stylosa Griff. }\end{array}$ & $\begin{array}{c}+ \\
\text { (hijau } \\
\text { pekat) }\end{array}$ & $\begin{array}{c}- \\
\text { (kuning) }\end{array}$ & $\begin{array}{c}+ \\
\text { (coklat } \\
\text { muda) }\end{array}$ \\
\hline $\begin{array}{l}\text { Rhizophora } \\
\text { mucronata Lam. }\end{array}$ & $\begin{array}{c}+ \\
\text { (hijau } \\
\text { pekat) }\end{array}$ & $\begin{array}{c}- \\
\text { (kuning) }\end{array}$ & $\begin{array}{c}+ \\
\text { (coklat } \\
\text { muda) }\end{array}$ \\
\hline $\begin{array}{l}\text { Avicennia marina } \\
\text { (Forsk.) Vierh. }\end{array}$ & $\begin{array}{c}+ \\
\text { (hijau } \\
\text { pekat) }\end{array}$ & $\begin{array}{c}+ \\
\text { (hijau muda) }\end{array}$ & $\begin{array}{c}+ \\
\text { (coklat } \\
\text { muda) }\end{array}$ \\
\hline
\end{tabular}

Hasil skrining fitokimia pada table 1 menunjukkan bahwa ekstrak kasar kulit batang C. decandra, C. tagal, B. cylindrica, B. gymnorrhiza, R. stylosa Griff., R. mucronata positif mengandung fenol dan tanin, sedangkan $A$. marina positif memiliki kandungan flavonoid, dan hasil negatif pada uji senyawa fenol dan tanin dengan tidak adanya perubahan warna pada sampel. Mangrove merupakan tumbuhan yang mampu hidup dengan kondisi substrat yang berlumpur, perairan dangkal di daerah pessisir dan memiliki salinitas yang tinggi. Menurut Bandaranayake (2002), metabolit sekunder yang ditemukan pada tumbuhan mangrove meliputi senyawa golongan alkaloid, fenolat, steroid, dan terpenoid. Senyawasenyawa ini memiliki efek toksik, farmaklogik dan ekologik yang penting.

Beberapa hasil penelitian menunjukkan bahwa tumbuhan mensintesis senyawa metabolit sekunder dalam jumlah yang sangat besar dibandingkan dengan hewan karena tumbuhan tidak memiliki kemampuan moblitas untuk menghindari serangan predator, sehingga tumbuhan memproduksi senyawa kimia sebagai salah satu mekanisme pertahanan diri dari serangan predator (Bandaranayake, 2002; Tong et al., 2006; Zhu et al., 2009).

Senyawa fenolik pada tumbuhan memiliki peran dalam proses reproduksi, mekanisme pertahanan diri dari serangan pathogen dan predator. Senyawa ini merupakan salah satu senyawa utama pada golongan senyawa metabolit sekunder). Fenolik merupakan senyawa metabolit sekunder yang terdapat dalam suatu organisme yang berfungsi untuk melindungi dari tumbuhan serangan herbivora serta melindungi dari kerusakan akibat pengaruh cahaya yang berlebihan dengan bertindak sebagai antioksidan, dan level kandungan fenolik bervariasi sesuai dengan kondisi (Bell, 1980; Setianigrum, 2016).

Flavonoid merupakan senyawa fenol, sehingga warnanya berubah ketika ditambah basa atau amoniak (Sitait, 2007). Flavonoid memiliki kemampuan menghentikan tahap awal reaksi, oleh karena itu flavonoid dapat menghambat peroksidasi lipid, menekan kerusakan jaringan oleh radikal bebas dan menghambat beberapa enzim (Latifah, 2015)

Tanin pada umumnya diperoleh dari tumbuhan pada bagian kayu, kulit dan buah. Sebagai salah satu senyawa senyawa aktif metabolit sekunder, tanin mempunyai fungsi sebagai anti bakteri, antioksidan, dan anti diare (Malangngi, 2012).

Secara umum metabolit sekunder berperan dalam mekanime pertahanan diri dari herbivore, mikroba, fungi, 
virus, serta berfungi untuk melindungi tumbuhan dari radiasi ultraviolet (Kutchan, 2001).

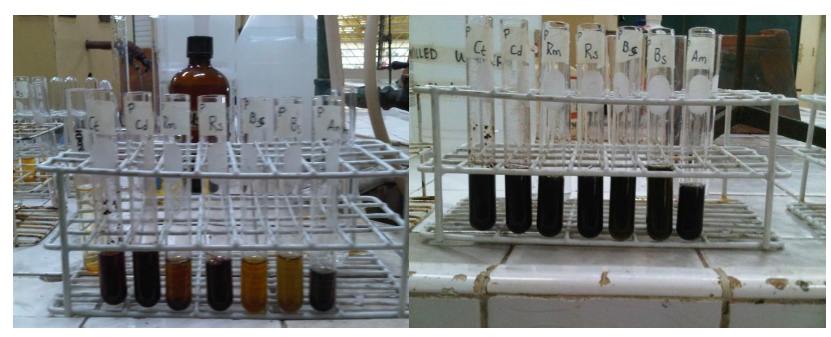

(a) Sebelum Uji

(b) Setelah Uji

Gambar 1. (a); (b). Uji Fenol

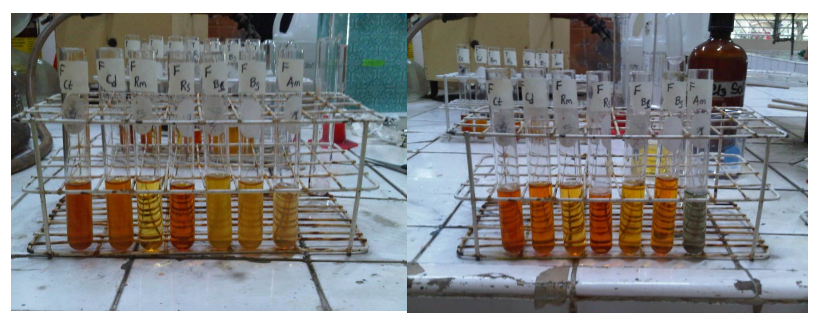

(c) Sebelum Uji

(d) Setelah Uji

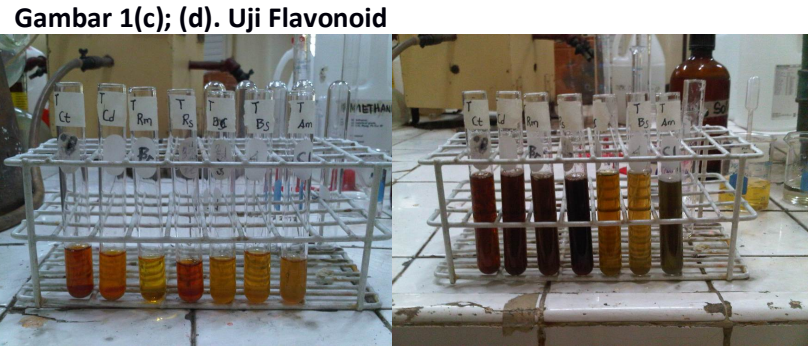

(e) Sebelum Uji

(f) Setelah Uji

Gambar 1 (e); (f). Uji Tanin

\subsection{Kromatografi lapis tipis (KLT)}

Hasil uji KLT ekstrak kasar kulit batang mangrove dapat dilihat pada gambar 2. Pemisahan senyawa fitokimia oleh KLT sangat tergantung pada pada pelarut yang digunakan. Hal ini ditunjukkan dengan perbedaan jumlah noda pada 2 variasi fase gerak yang digunakan. yaitu campuran etil asetat: asam formic: asam asetat (100:11:26) dan 1 -butanol: etanol: aquades (40:10:50). Dari kedua fase gerak tersebut, eluen yang mampu menghasilkan pemisahan yang baik adalah 1 -butanol: etanol: aquades. Hal ini dapat dilihat dengan adanya noda yang terpisah dengan baik dari sampel ekstrak kasar kulit batang mangrove dan jumlah noda sebanyak 2 noda untuk spesies $A$. marina dan 4 noda untuk spesies $R$. stylosa.

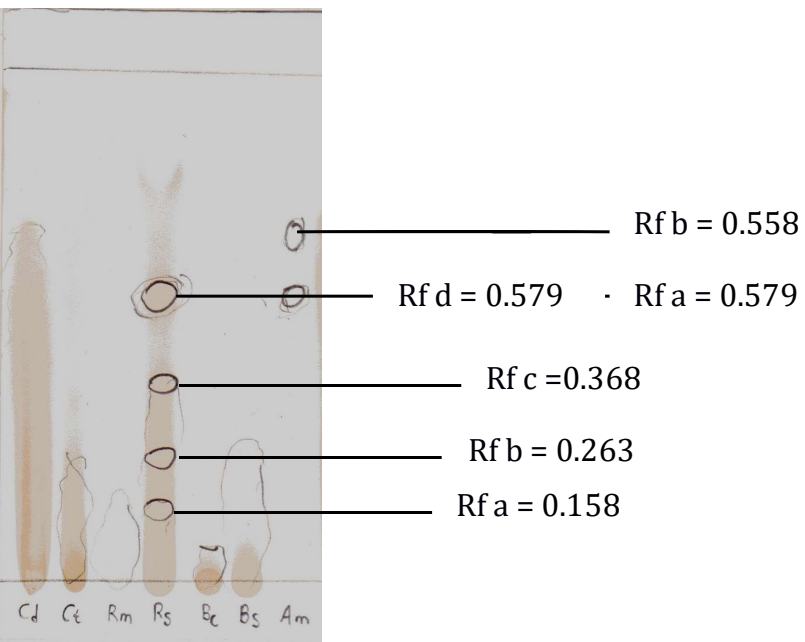

Gambar 2. Profil KLT ekstrak kasar kulit batang mangrove (Fase gerak berupa 1-butanol: etanol: aquades, 40:10:50 (v/v)) Cd: Ceriops decandra (Griff.) Ding Hou; Ct: Ceriops tagal (Perr.) C.B. Rob.; Rm: Rhizophora mucronata Lam.; Rs: Rhizophora stylosa Griff; Bc: Bruguiera cylindrica (L.) Blume; Bg: Bruguiera gymnorrhiza (L) Lam; Am: Avicennia marina (Forsk).

Noda-noda yang terpisah dapat dilihat di bawah sinar UV dengan panjang gelombang $254 \mathrm{~nm}$. Hasil perhitungan nilai Rf dari pemisahan ekstrak kasar kulit batang mangrove dapat dilihat pada tabel 2. Noda-noda ini terpisah berdasarkan tingkat kepolarannya. Noda yang memiliki nilai Rf yang kecil diduga cenderung bersifat polar karena noda tersebut lebih terdistribusi ke fase diam yang cenderung bersifat polar. Noda yang memiliki Rf yang tinggi, cenderung terdistribusi ke dalam fase gerak yang kepolarannya lebih kecil dibandingkan dengan fase diamnya.

Data pada tabel 2 menunjukkan bahwa dari 7 spesises mangrove yang di teliti, hanya 2 spesies saja yang menunjukkan hasil positif, yaitu ekstrak kasar kulit batang $R$. mucronta memiliki 4 noda dengan nilai Rf masing-masing 0,16 ; 0,$27 ; 0,38$ dan 0,11 , dan diduga mengandung senyawa flavonoid dan asam fenolik. Sedangkan $A$, marina menunjukkan 2 noda dengan nilai Rf 0,61 dan 0,72, dan diduga adanya kandungan asam fenolik. Berdasarkan hasil penelitian Ćetković et al., (2003), nilai Rf dengan kisaran antara 0, 18; 0,26 dan 0,30 merupakan kisaran nilai $\mathrm{Rf}$ yang teridentifikasi sebagai senyawa flavonoid daa nilai $\mathrm{Rf}$ dengan kisaran 0,63 0,84 merupakan senyawa asam fenolik.

Tabel 2

Hasil Pemisahan Golongan Senyawa Aktif Ekstrak Kasar Kulit Batang Mangrove Menggunakan KLT

\begin{tabular}{lccccc}
\hline Species & Rf & Rf & Senya & Warna & Refere \\
& sa & Pust & wa & di & nsi \\
& mp & aka & yang & bawah & \\
& el & & $\begin{array}{c}\text { teride } \\
\text { ntifika }\end{array}$ & Lampu & UV 254 \\
& & & si & nm \\
\hline Ceriops decandra & - & - & - & Tidak \\
(Griff.) Ding Hou & & & & berwar \\
& & & & na \\
Ceriops tagal & - & - & - & Tidak \\
(Perr.) C.B. Rob. & & & & berwar \\
\hline
\end{tabular}




\begin{tabular}{|c|c|c|c|c|c|}
\hline $\begin{array}{l}\text { Bruguiera } \\
\text { cylindrical }\end{array}$ & - & - & - & $\begin{array}{c}\text { na } \\
\text { Tidak } \\
\text { berwar } \\
\text { na }\end{array}$ & \\
\hline $\begin{array}{l}\text { Bruguiera } \\
\text { gymnorrhiza (L) }\end{array}$ & - & & - & $\begin{array}{c}\text { Tidak } \\
\text { berwar } \\
\text { na }\end{array}$ & \\
\hline \multirow[t]{4}{*}{$\begin{array}{l}\text { Rhizophora } \\
\text { stylosa Griff. }\end{array}$} & $\begin{array}{c}0,1 \\
6\end{array}$ & 0,18 & $\begin{array}{l}\text { Flavon } \\
\text { oid }\end{array}$ & oranye & $\begin{array}{c}\text { Ćetkov } \\
\text { ić et }\end{array}$ \\
\hline & $\begin{array}{c}0,2 \\
7\end{array}$ & 0,26 & $\begin{array}{l}\text { Flavon } \\
\text { oid }\end{array}$ & oranye & $\begin{array}{c}\text { al., } \\
2003\end{array}$ \\
\hline & $\begin{array}{c}0,3 \\
8\end{array}$ & 0,30 & $\begin{array}{l}\text { Flavon } \\
\text { oid }\end{array}$ & oranye & \\
\hline & $\begin{array}{c}0,1 \\
1\end{array}$ & $\begin{array}{c}0,63 \\
- \\
0,84\end{array}$ & $\begin{array}{l}\text { Asam } \\
\text { fenoli } \\
\mathrm{k}\end{array}$ & oranye & \\
\hline $\begin{array}{l}\text { Rhizophora } \\
\text { mucronata Lam. }\end{array}$ & - & & - & & \\
\hline $\begin{array}{l}\text { Avicennia } \\
\text { marina (Forsk.) } \\
\text { Vierh. }\end{array}$ & $\begin{array}{c}0,6 \\
1\end{array}$ & $\begin{array}{c}0,63 \\
- \\
0,84\end{array}$ & $\begin{array}{l}\text { Asam } \\
\text { fenoli } \\
\mathrm{k}\end{array}$ & kuning & \\
\hline & $\begin{array}{c}0,7 \\
2\end{array}$ & $\begin{array}{c}0,63 \\
- \\
0,84\end{array}$ & $\begin{array}{l}\text { Asam } \\
\text { fenoli } \\
k\end{array}$ & kuning & \\
\hline
\end{tabular}

Keterangan: Tanda (-): tidak terkandung senyawa

Hasil penelitian ini didukung oleh Harborne (1989) yang menunjukkan bahwa Bryophyta secara teratur memproduksi polifenol, termasuk juga flavonoid, tapi pada tumbuhan vaskular, hampir semua polfenol ditemukan. Fenolik sangat jarang ditemukan pada bakteri, fungi dan alga.

Beberapa senyawa organik ada yang berwarna dan ada yang tidak berwarna. Pada kebanyakan penelitian, pengamatan noda-noda hasil pemisahan senyawa di bawah cahaya UV dengan panjang gelombang $254 \mathrm{~nm}$ dapat memberikan hasil visualisai yang baik dari senyawa fitokimia. Plat KLT secara umum memiliki indikator cahaya berpendar sehingga plat KLT dapat memancarkan cahaya hijau yang dapat berpendar dibawah cahaya UV dengan panjang gelombang 254 $\mathrm{nm}$.

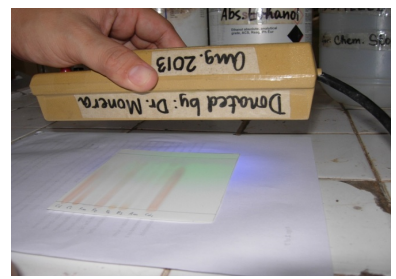

(a)

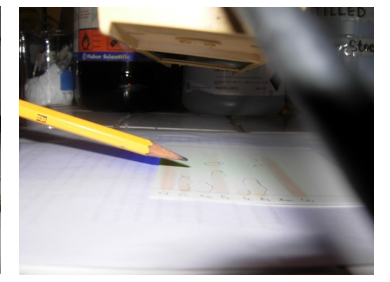

(b)
Gambar 2 (a); (b). Visualisasi dibawah cahaya UV (254nm

Pada penelitian ini, visualisasi dilakukan dengan 2 metode. Metode pertama, cahaya UV dengan panjang gelombang pendek $(254 \mathrm{~nm})$. Noda-noda pada plat KLT dapat diamati secara langsung dengan melatakan KLT dibawah cahaya UV setelah diangkat dari dalam wadah pengembang. Noda-noda yang terlihat pada KLT kemudian di tandai dengan pencil seperti yang ditunjukkan pada gambar 2(a) dan 2(b).

Metode kedua dilakukan dengan menyemprotkan plat KLT dengan asam sulfur. Profil KLT menunjukkan hasil negatif setelah di semprotkan dengan asam sulfur, yang ditampilkan pada gambar 3 (a), 3(b) dan 3(c). Secara umum, penggunaan 2 metode visualisasi pada sampel, dapat memberikan informasi penting jika senyawa yang ingin diteliti dapat tidak teramati.

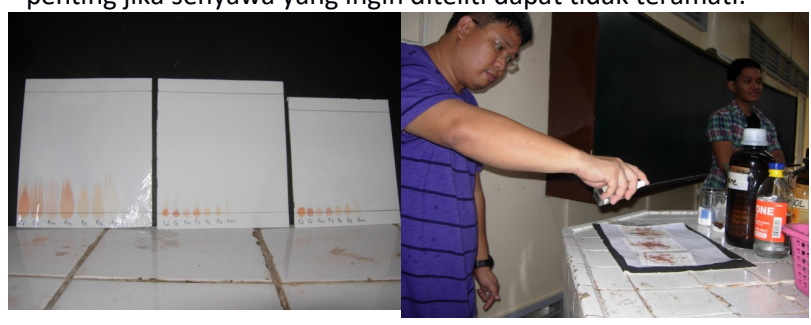

(a)

(b)

(c)

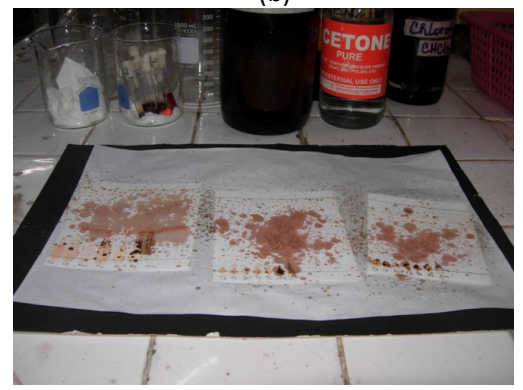

Gambar 3. (a); (b); (c). Visualisasi setelah penyemprotan asam sulfur

\section{Kesimpulan}

Skrining fitokimia menunjukkan bahwa pada ekstrak kulit batang Ceriops decandra (Griff.) Ding Hou, Ceriops tagal (Perr.) C.B. Rob., and Bruguiera gymnorrhiza (L) Lam, Bruguiera cylindrica, Rhizophora stylosa Griff., Rhizophora mucronata Lam dan Avicennia marina (Forsk.) Vierh mengandung senyawa fenol dan tanin, sedangkan flavonoid hanya ditemukan pada ekstrak kasar kulit batang Avicennia marina (Forsk.) Vierh. Namun analisis KLT menunjukkan bahwa terdapat perbedaan terhadap komposisi senyawa metabolit sekunder. Hasil penelitian ini dapat mengarah pada pemurnian, karakterisasi senyawa aktif dari ekstak kasar kulit batang dari 7 spesies mangrove ini.

\section{Bibliografi}

Abed, S. A., Sirat, H Mohd., \& Taher, M., 2013. Total phenolic, antioxidant, antimicrobial activities and toxicity study of Gynotroches axillaris Blume (Rhizophoraceae). EXCLI Journal. 12, 404-412.

Abeysinghe, P. D., Wanigatunge, R. P., 2006. Evaluation of antibacterial activity of different mangrove plant. Ruhuna J. Sci. 1, 108- 116.

Alongi, D.M., 2008. Mangrove Forests: Resilience, Protection from Tsunamis, and Responses to Global Climate Change. Estuar. Coast. Shelf Sci. 76, 1-13.

Asha, K.K., Suseela, M. and Lakshmanan, P.T., 2012. Flavonoids and phenolic compounds in two mangrove species and their antioxidant property. Indian Journal of GeoMarine Sciemces. 41(3), 259-264. 
Ashton, E. C., Macintosh, D. J., 2002. Preliminary assessment of the plant diversity and community ecology of the Sematan mangrove forest, Sarawak, Malaysia. Forest Ecol Managem. 166, 111-29.

Bandaranayake, W. M., 1998. Traditional and medicinal uses of mangroves. Mangroves and Salt Marshes. 2, 133-48.

Bandaranayake, W. M., 2002. Bioactivities, bioactive compounds and chemical constituents of mangrove plants. Wetl. Ecol. Manag. 10, 421-452.

Bell, H. K., Duewell, H., 1961. Triterpenoids from the bark of the Avicennia marina. Aust. J. Chem. 14, 662-664.

Bell, E. A., 1980. Secondary Plant Products, Bell, E.A and Charlwood, B.W. (Eds.), Enciclopedia of Plant Physiology, New Series, vol. 8. Springer-Verlag, Berlin, p.11.

Brown, W.H., Fischer, A.F., 1981. Philippine Mangrove Swamps, Bureau of Printing: Manila, Philippines, $p$. 132.

Bunyapraphatsara, N., Jutiviboonsuk, A., Sornlek, P., Therathanathorn, W., Aksornkaew, S., Fong, H. H. S., Pezzuto, J.M., Kosmeder, Jerry., 2003. Pharmacological studies of plants in the mangrove forest. Thai Journal of Phytopharmacy. 10(2), 2546.

Calumpong, H.P., Menez, E.G., 1997. Field guide to common mangrove, seagrass and algae of the Philppines. Bookmark, Inc. Makati City, Philippines.

Ćetković, G. S., Đilas, S. M., Čanadanović-Brunet, J. M., and Tumbas, V.T., 2003. Thin-Layer Chromatographty analysis and scabenging activity of Marigold (Calendula officinalis L.) extracts. APTEFF. 34, 93-102.

Chandrasekaran, M., Kannathasan, K., Venkatesalu, V., Prabhakar, K., 2009. Antibacterial activity of some salt marsh halophytes and mangrove plants against methicillin resistant Staphylococcus aureus. W. J. Micro Biotech. 25, 155-160.

Croteau, R., Kutchan, T. M., Lewis, N. G., 2000. Natural Products (Secondary Metabolites). Biochemistry \& Molecular Biology of Plants, B. Buchanan, W. Gruissem, R. Jones, (Eds.), American Society of Plant Physiologists.

Fauvel, M. T., Taoubi, K., Gleye, J., Fouraste, I., 1993. Phenylpropanoid glycosides from Avicennia marina. Planta Med. 59, 387- 387.

Giri, C., Zhu, Z., Tieszen, L.L., Singh, A., Gillette, S. \& Kelmelis, J.A., 2008. Mangrove forest distributions and dynamics (1975-2005) of the tsunami-affected region of Asia. Journal of Biogeography. 35, 519-528.

Guevara, B.Q., 2005. A Guidebook to plant screening: Phytochemical and biological. Universitu of Santo Tomas Publishing house. Espana. Manila.Harborne,
J.B., 1989. Methods in Plant Biochemistry, vol. 1. Plant Phenolics, Dey, P.M. and Harborne, J.B. (Eds.), Academic Press, London.

Harborne, J.B., 1989. Methods in Plant Biochemistry, vol. 1. Plant Phenolics, Dey, P.M. and Harborne, J.B. (Eds.), Academic Press, London.

Haq, MIdadul., Sani, W., Hossain, A. B. M. S., Mat Taha, R and Monneruzzaman, K. M., 2011. Total phenolic contents, antioxidant and antimicrobial activities of Bruguiera gymnorrhiza. Journal of Medicinal Plants Research. 5(17), 4112-4118.

Howlader, Md. S. I., Dey, S. K., Hira, A., Ahmed, Arif., 2012. Evaluation of antinociceptive and antioxidant properties of the ethanolic extract of Sonneratia caseolaris leaves. Der Pharmacia Sinica. 3 (5), 536-541.

Huang, X. Y., Wang, Q., Liu, H. L., Zhang, Y., Xin, G. R., Shen, X., 2009. Diastereoisomeric macrocyclic polydisulfides from the mangrove Bruguiera gymnorrhiza. Phytochemistry. 70, 2096-100.

Kathiresan, K., 2003. Insect foliovory in mangroves. Indian Journal of Marine Sciences. 32(3), 237-239.

Kutchan, T.M. 2001, Plant Physiol. p. 125, 58.

Lakshmanan, G., Rajeshkannan, C., Kavitha, A., Mekala B., and Kamaladevi, N., 2013. Preliminary screening of biologically active constituents of Suaeda monoica and Sesuvium portulacastrum from palayakayal mangrove forest of Tamilnadu. Journal of Pharmacognosy and Phytochemistry. 2(3), 149-152.

Lattanzio, V., Lattanzio, V. M. T. and Cardinali, A., 2006. Role of phenolics in the resistance mechanisms of plants against fungal pathogens and insects. Phytochemistry: Advances in Research. 23-67.

Maobe, M. A.G., Gitu, L., Gatebe, E., and Rotich, H., 2012. Phytochemical Analysis of Phenol and Flavonoid in Eight Selected Medicinal Herbs Used for the Treatment of Diabetes, Malaria and Pneumonia in Kisii, Kenya. Academic Journal of Cancer Research. 5 (2), 31-39.

Miles D.H., Kokpol U., Chittawong V., Tip-Pyang S., Tunsuwan K \& Nguyen C., 1998. Mangrove forests-The importance of conservation as a bioresource for ecosystem diversity and utilization as a source of chemical constituents with potential medicinal and agricultural value. IUPAC. 70 (11), 1-9.

Nurhanan, M. Y, Asiah, O., Mohd Ilham, M. A, Siti Syarifah, M. M, Norhayati, I., Lili Sahira, H., 2008. Antiproliferative activities of 32 Malaysian plant species in breast cancer cell lines. J Trop For Sci. 20, 77-81. 
Nguyen-Pouplin, J., Tran, H., Phan, T.A., Dolecek, C., Farrar, J., Tran, T.H., 2007. Antimalarial and cytotoxic activities of ethnopharmacologically selected medicinal plants from South Vietnam. J Ethnopharmacol. 109, 417-27.

Ravichandran, A., Anthonisamy, A., Kannupandi T., and Balasubramanian, T., 2007. Leaf choice of herbivorous mangrove crabs. Research Journal of Environmental Sciencies. 1(1), 26-30.

Shamsuddin, A.A., Najiah, Suvik, M., Azariyah, A., M.N., Kamaruzzaman, B.Y., Effendy, A.W. and Akbar John, B., 2013. Antibacterial Properties of Selected Mangrove Plants Against Vibrio Species and its Cytotoxicity Against Artemia salina. World Applied Sciences Journal. 25 (2), 333-340.

Swain, T., 1975. The Flavonoids, Harborne, J.B., Mabry, T.J., and Mabry, H. (Eds.), Chapman \& Hall, London, p.1096.

Swain, T., 1977. Ann. Rev. Plant Physiol. 28, 479.

Tamilselvi, N., Krishnamoorthy, P., Dhamotharan. R., Arumugam, $P$ and Sagadevan, E., 2012. Analysis of total phenols, total tannins and screening of phytocomponents in Indigofera aspalathoides (Shivanar Vembu) Vahl EX DC. Journal of Chemical and Pharmaceutical Research. 4(6), 3259-3262.

Tiwari, P., Rahuja, N, Kumar. R., Lakshmi, V., Srivastava, M.N., Agarwal, S.C., 2008. Search for antihyperglycemic activity in few marine flora and fauna. Indian J Sc Technol. 1(5), 1-5.

Tong, Y.F., Lee, S.Y., and Morton, B., 2006. The herbivore assemblage, herbivory and leaf chemistry of the mangrove Kandelia obovata in two contrasting forests in Hong Kong Wetlands Ecology and Management. 14, 39-52.

Tomlinson P.B., 1994. The Botany of Mangroves. Cambridge University Press. New York, USA. pp. 163-170.

Zohra, S. F., Meriem, B., Samira, S., Muneer, M.S.A., 2012. Phytochemical Screening and identification of some compounds from Mallow. J. Nat. Prod. Plant Resour. 2 (4), 512-516.

Zhu, Feng., Xin Chen., Yihua Yuan, Meizhen Huang., Huili Sun and Wenzhou Xiang., 2009. The Chemical Investigations of the Mangrove Plant Avicennia marina and its Endophytes. The Open Natural Products Journal. 2, 24-32. 